\title{
Deoxyribonucleic Acid Base Composition of Dermatophilus congolensis and Geodermatophilus obscurus
}

\author{
W. A. SAMSONOFF, M. A. DETLEFSEN, A. F. FONSECA,' AND M. R. EDWARDS
}

Division of Laboratories and Research, New York State Department of Health, Albany, New York 12201

The base compositions of the deoxyribonucleic acids (DNAs) extracted from four representative strains of Dermatophilus congolensis and six of Geodermatophilus obscurus, which are described in the literature as belonging to the family Dermatophilaceae (Actinomycetales), were determined. The range of guanine plus cytosine contents $(\mathrm{G}+\mathrm{C})$ of their DNAs was 57.4 to $58.7 \mathrm{~mol} \%$ for $D$. congolensis and 72.9 to $74.6 \mathrm{~mol} \%$ for $G$. obscurus. This difference in DNA base composition is considered great enough to suggest a substantial genetic heterology between the two groups of organisms.

Procaryotic microorganisms of the genera Dermatophilus van Saceghem 1915 and Geodermatophilus Luedemann 1968 are currently assigned to the family Dermatophilaceae Austwick 1958 in the Actinomycetales (8). The type species designated for these genera are Dermatophilus congolensis and Geodermatophilus obscurus.

These microorganisms possess a type III cell wall (2) and are gram-positive aerobes. Although they have a worldwide distribution, they occupy different ecological niches (9). Dermatophilus has been repeatedly isolated from wild and domestic animals and is recognized as the cause of severe skin lesions in these animals. Occasionally it infects man. On the other hand, Geodermatophilus includes soil-dwelling microorganisms which have not yet been shown to be pathogenic to animals. Conversely, Dermatophilus has not been found in the soil.

In view of the resemblances that exist between these actinomycetes, questions have been raised as to the possible evolutionary derivation of $D$. congolensis from a soil species such as $G$. obscurus (9).

Light and electron microscope studies have indeed shown morphologic similarities between these species $(1,6,7,10,12-14,19)$. However, distinct ultrastructural differences between them have also been demonstrated in this laboratory (A. F. Fonseca and M. R. Edwards, unpublished results), especially in relation to their motile cells. Furthermore, the extensive branching filamentous growth phase, which has been found in all strains of Dermatophilus that have so far been investigated, apparently is not produced by Geodermatophilus. In our hands, even when growing one of Luedemann's

'Present address: Department of Microbiology, School of Medicine, University of O'Porto, Portugal. strains (G-17) in the same medium reported by that author (14), only rudimentary short filaments were obtained.

The uncertainties and difficulties encountered in classifying organisms such as these are evident, especially when the emphasis is placed on their morphological features. Although such features play a major role in taxonomy, the other individual characteristics (serologic, genetic, etc.) are important in establishing phylogenetic relationships.

In modern microbial taxonomy, the comparative analyses of deoxyribonucleic acid (DNA) base compositions, expressed as the mean moles percent of guanine plus cytosine $(\mathrm{mol} \%$ $\mathrm{G}+\mathrm{C}$ or $\mathrm{G}+\mathrm{C}$ value), are used as a cardinal criterion (17).

In this paper, the $\mathrm{G}+\mathrm{C}$ values obtained from several isolates of $D$. congolensis and $G$. obscurus are presented.

\section{MATERIALS AND METHODS}

Organisms. Four strains of $D$. congolensis and six of $G$. obscurus were used. Their designations and origins were as follows: $D$. congolensis A-4 from cattle, Rhodesia; A-26 from squirrel, British Columbia, Canada; A-22 and A-33 from deer, New York State. G. obscurus G-4, G-5, G-7, G-9 and G-17 were the same strains reported by Luedemann (14); 22-68 was that of Ishiguro and Wolfe (12). These strains of Geodermatophilus were soil isolates. Stock cultures of all Dermatophilus and Geodermatophilus strains used in this study are maintained by the Laboratories for Mycology in this Division. Escherichia coli (strain K-12 C-600), which was employed as one of the controls, was provided by Robert Trimble of this Division.

Growth and harvesting conditions. Cultures of $D$. congolensis in our laboratory were grown on agar slants containing brain-heart infusion (BHI, Difco, Ann Arbor, Mich.). The G. obscurus cultures were grown on Luedemann's $6 \mathrm{~b}$ medium (14) with $1.5 \%$ agar (Difco). In all of the above cases, cultures were 
maintained at room temperature and transferred monthly. To harvest cells, broth was used instead of agar. It was either $\mathrm{BHI}$ and $6 \mathrm{~b}$, respectively, or a special medium designated CYT and prepared by the addition of $0.1 \%$ yeast extract and $0.1 \%$ tryptone to an inorganic salt solution (4) at $\mathrm{pH} 7.2$. The cultures were grown at 30 to $34^{\circ} \mathrm{C}$, agitated continuously using a magnetic stirrer or a rotary motion shaker, and harvested at different stages of growth. Young cells of Dermatophilus (filaments and motile cells) were obtained after 3 to $18 \mathrm{~h}$; the older cells (coccoid forms) were obtained after 2 to 3 days. In the case of Geodermatophilus, harvesting times were extended to 18 to $24 \mathrm{~h}$ for young cells and 3 to 5 days for older cells. Cultures of $E$. coli were grown at $30^{\circ} \mathrm{C}$ in nutrient broth (Difco) with continuous agitation, as indicated above for the other organisms.

In all cases, cells were harvested by centrifugation $(1,000 \times g)$, washed at least five times with phosphate-buffered saline ( $\mathrm{pH} 7.2$ ), quickly frozen in dry ice, and stored at $-20^{\circ} \mathrm{C}$.

DNA extraction. The procedure described by Grady et al. (11) was, in general, followed in this study. The DNA of $E$. coli was used as a standard. In most cases, it was necessary to grind the cells of Dermatophilus and Geodermatophilus in a mixture with glass beads and dry ice. The whole mixture containing broken cells was then treated for $1 \mathrm{~h}$ with lysozyme and another hour with Pronase, prior to the addition of the sodium lauryl sulfate (3). Only a few strains of both Dermatophilus and Geodermatophilus lysed easily upon treatment with lysozyme or sodium dodecyl sulfate alone without the grinding procedure. The coliphage T2 DNA which was also used as a standard in our study was a gift from Robert Trimble.

Purified DNA solutions were stored at 2 to $4^{\circ} \mathrm{C}$ in the presence of chloroform. Their concentrations were estimated by ultraviolet absorption at $260 \mathrm{~nm}$ using a Gilford model 2400 spectrophotometer and assuming $E_{1 \mathrm{~cm}}^{260}=200$. These preparations had absorbancy ratios $\left(A_{260} / A_{280}\right)$ of 1.8 to 1.9 and exhibited hyperchromicities ranging from 26 to $37 \%$.

Determination of the DNA base compositions: (i) $T_{m}$ method. To determine the midpoint in the hyperchromic shift upon thermal denaturation $\left(T_{m}\right)$ at 260 $\mathrm{nm}$, a Gilford model 2400 spectrophotometer equipped with a NESLAB model PT-2 temperature programmer and a Haake water bath was used. The test samples and the standard solutions chosen as references were extensively dialyzed against $1 \times$ SSC (or $0.1 \times$ SSC) and denatured at a concentration of 25 to $40 \mu \mathrm{g} / \mathrm{ml}$. When SSC was used as the solvent, the $T_{m}$ results were related to the $\mathrm{G}+\mathrm{C}$ values by the equation $\mathrm{mol} \% \mathrm{G}+\mathrm{C}=\left(T_{m}-69.3\right) \times(2.44)$ of Marmur and Doty (16). When the solvent was $0.1 \times$ $\mathrm{SSC}$, the equation used was mol\% $\mathrm{G}+\mathrm{C}=\left(T_{m}-\right.$ 53.9) $\times$ (2.44) of Mandel and Marmur (15).

(ii) Buoyant density method. For a comparison with the $T_{m}$ results, the $\mathrm{G}+\mathrm{C}$ value was determined on some samples using the buoyant density method (21) and calculated by using the equation $\mathrm{g} / \mathrm{cm}^{3}=$ $1.660+0.098(\mathrm{~mol} \% \mathrm{G}+\mathrm{C})$. As a standard reference for the Geodermatophilus DNA determinations $E$. coli DNA (density $1.7100 \mathrm{~g} / \mathrm{cm}^{3}$ ) was used, whereas for Dermatophilus, T2 phage DNA (density $1.702 \mathrm{~g} /$ $\mathrm{cm}^{3}$ ) was preferred. The respective densities of these two reference DNAs were consistent when compared with each other.

DNA sedimentation velocities. Sedimentation velocities were determined by the boundary method (20) as a measure for molecular weight and size dispersion. A DNA preparation (30 to $50 \mu \mathrm{g} / \mathrm{ml}$ ) was run in an SSC solvent at $20^{\circ} \mathrm{C}$ at rotor speeds of 36,000 and 48,000 rpm using a Bechman model E ultracentrifuge equipped with a photoelectric scanner.

\section{RESULTS}

The different growth media employed for the Dermatophilus or Geodermatophilus cultures and the differences in culture age did not alter significantly the results of the DNA analyses. Thus, no further reference will be made to these parameters.

Thermal denaturation. The $\mathrm{G}+\mathrm{C}$ values of the four Dermatophilus isolates fell within the range of 57.4 to $58.7 \mathrm{~mol} \%$ (Table 1). These were results from three to eight runs for each isolate. In contrast, the $\mathrm{G}+\mathrm{C}$ values of the six Geodermatophilus isolates were much higher, ranging from 72.9 to $74.6 \mathrm{~mol} \%$ (Table 2). In this case, three to four $T_{m}$ determinations were made for each isolate.

Buoyant density. For two strains of Dermatophilus, the $\mathrm{G}+\mathrm{C}$ values ( 60 and $61.3 \mathrm{~mol} \%$ ) obtained by this method were slightly higher than their respective $T_{m}$ values (Table 1). In the case of Geodermatophilus, the $\mathrm{G}+\mathrm{C}$ values obtained by the buoyant density procedure (73.5 to $75.9 \mathrm{~mol} \%$ ) agreed favorably with those of the $T_{m}$ studies (Table 2).

Sedimentation velocity. The sedimentation velocity experiments were performed to show

TABLe 1. Dermatophilus congolensis

\begin{tabular}{lccc}
\hline Strain no. & $\begin{array}{c}\text { Mol\% G+C from } \\
T_{m}\end{array}$ & $\begin{array}{c}\text { Mol\% } \mathrm{G}+\mathrm{C} \\
\text { from } \rho^{a}\end{array}$ & $S$ value \\
\hline A-22 & $58.7 \pm 0.1$ & 61.3 & 22.8 \\
A-4 & $58.1 \pm 0.5$ & 60.1 & 24.6 \\
A-33 & $57.4 \pm 0.2$ & & 21.0 \\
A-26 & $58.2 \pm 0.2$ & & 30.4 \\
\hline
\end{tabular}

a Buoyant density.

TABLE 2. Geodermatophilus obscurus

\begin{tabular}{lccc}
\hline Strain no. & $\begin{array}{c}\text { Mol\% G+C } \\
\text { from } T_{m}\end{array}$ & $\begin{array}{c}\text { Mol\% G+C } \\
\text { from } \rho^{\alpha}\end{array}$ & $S$ value \\
\hline G-17 & $73.4 \pm 0.4$ & 74.0 & 21.8 \\
$22-68$ & $73.6 \pm 0.3$ & 73.5 & 25.8 \\
G-9 & $74.6 \pm 0.2$ & 75.9 & 22.6 \\
G-5 & $74.4^{b}$ & & \\
G-4 & $73.0 \pm 0.1$ & & 24.1 \\
G-7 & $72.9 \pm 0.1$ & & 29.5 \\
\hline
\end{tabular}

${ }^{a}$ Buoyant density.

${ }^{b}$ Only one determination. 
the molecular weight dispersion of the DNA preparations, i.e., as a function of the method used. The glass-grinding technique always produced DNA with a broad sedimenting boundary, whereas sharp boundaries were seen when other extraction techniques were used. The differences in DNA molecular sizes, however, were not in a range that could affect the $T_{m}$ temperatures, and comparable results were obtained from both DNA with broad or sharp sedimentation boundaries as would be expected (16). The sedimentation velocity values for Dermatophilus DNA ranged from 21.0S to $30.4 S$ (Table 1), and for Geodermatophilus DNA they ranged from $21.8 \mathrm{~S}$ to $29.5 \mathrm{~S}$ (Table 2).

\section{DISCUSSION}

Arguments for considering the comparative analysis of DNA base ratios in bacterial taxonomy have been reviewed by Marmur et al. (17) and more recently by DeLey (5). It has been generally accepted that organisms with similar $G+C$ values may or may not be related; but those with significantly different values (differences of 10 to $20 \mathrm{~mol} \%$ or more) cannot be closely related. Indeed, an analysis of strains belonging to well established species have shown that their $\mathrm{G}+\mathrm{C}$ values are very close to one another (see compilation of data by Normore and Brown [18]). As Sueoka (22) suggested, when differences are more than 10 mol\% $\mathrm{G}+\mathrm{C}$, the probability for the DNA molecules to have identical nucleotide sequences of "gene" length is low. In extreme cases, as discussed by DeLey (5), differences of $20 \mathrm{~mol} \%$ or more should be considered as the significant values to indicate evolutionary divergency among microorganisms, and hence a lack of taxonomic relationship. The difference of 15 mol\% between the $\mathrm{G}+\mathrm{C}$ values of Dermatophilus and Geodermatophilus apparently does not substantiate the idea that Dermatophilus could have been derived from Geodermatophilus (9).

\section{ACKNOWLEDGMENTS}

This study was supported in part by Public Health Service research grant number 5R01 AI 08119-06 from the National Institute of Allergy and Infectious Diseases.

We wish to thank Morris A. Gordon from this Division for providing most of the cultures used in this study, Oranda Kao for assisting us with the sedimentation velocity experiments, and Inge Panko for her technical assistance.

\section{REPRINT REQUESTS}

Address reprint requests to: Dr. W. A. Samsonoff, Division of Laboratories and Research, New York State Department of Health, Albany, NY 12201.

\section{LITERATURE CITED}

1. Austwick, P. K. C. 1958. Cutaneous streptothricosis, mycotic dermatitis and strawberry foot rot and the genus Dermatophilus van Saceghem. Vet. Rev. Annot. 4:33-48.

2. Becker, B., M. P. Lechevalier, and H. A. Lechevalier. 1965. Chemical composition of cell-wall preparations from strains of various form-genera of aerobic actinomycetes. Appl. Microbiol. 13:236-243.

3. Bradley, S. G., G. H. Brownell, and J. Clark. 1973. Genetic homologies among nocardiae and other actinomycetes. Can. J. Microbiol. 19:1007-1014.

4. Castenholz, R. W. 1967. Aggregation in a thermophilic Oscillatoria. Nature (London) 215:1285-1286.

5. DeLey, J. 1970. Molecular techniques and applications in bacterial taxonomy, p. 317-327. In $\mathrm{H}$. Prauser (ed.), The Actinomycetales. Gustav Fisher Verlag, Jena.

6. Fonseca, A. F. 1971. Ultrastructure of the actinomycete Geodermatophilus obscurus, p. 248-249. In C. J. Arceneaux (ed.), Proc. 29th Annu. Meet. Electron Microscopy Society of America, Boston, Mass. Clayton Publishing Division, Baton Rouge, Louisiana.

7. Gordon, M. A. 1964. The genus Dermatophilus. J. Bacteriol. 88:509-522.

8. Gordon, M. A. 1974. Family V. Dermatophylaceae, p. 723-726. In R. E. Buchanan and N. E. Gibbons (ed.), Bergey's manual of determinative bacteriology. The Williams and Wilkins Co., Baltimore.

9. Gordon, M. A. 1976. Characteristics of Dermatophilus congolensis, its affinities with the Actinomycetes and differentiation from Geodermatophilus, p. 187-201. In D. H. Lloyd and K. C. Sellers (ed.), Dermatophilus infection in animals and man. Academic Press Inc., London.

10. Gordon, M. A., and M. R. Edwards. 1963. Micromorphology of Dermatophilus congolensis. J. Bacteriol. 86:1101-1115.

11. Grady, L. J., D. B. Cowie, and W. P. Campbell. 1971. Deoxyribonucleic acid hybridization analysis of the defective bacteriophage carried by strain 15 of Escherichia coli. J. Virol. 8:850-855.

12. Ishiguro, E. E., and R. S. Wolfe. 1970. Control of morphogenesis in Geodermatophilus: ultrastructural studies. J. Bacteriol. 104:566-580.

13. Ishiguro, E. E., and R. S. Wolfe. 1974. Induction of morphogenesis in Geodermatophilus by inorganic cations and by organic nitrogenous cations. J. Bacteriol. 117:189-195.

14. Luedemann, G. M. 1968. Geodermatophilus, a new genus of the Dermatophilaceae (Actinomycetales). J. Bacteriol. 96:1848-1858.

15. Mandel, M., and J. Marmur. 1968. Use of ultraviolet absorbance-temperature profile for determining the guanine plus cytosine content of DNA, p. 195-206. In L. Grossman and K. Moldave (ed.), Methods in enzymology, vol. 12B. Academic Press Inc., New York.

16. Marmur, J., and P. Doty. 1962 Determination of the base composition of deoxyribonucleic acid from its thermal denaturation temperature. J. Mol. Biol. 5:109-118.

17. Marmur, J., S. Falkow, and M. Mandel. 1963. New approaches to bacterial taxonomy. Annu. Rev. Microbiol. 17:329-372.

18. Normore, W. M., and J. R. Brown. 1970. Guanine plus cytosine $(\mathrm{G}+\mathrm{C})$ composition of bacteria, p. H-24-H-75. In H. A. Sober (ed.), CRC handbook of biochemistry, selected data for molecular biology, 2nd ed. The Chemical Rubber Co., Cleveland.

19. Roberts, D. S. 1961. The life cycle of Dermatophilus dermatonomus, the causal agent of bovine mycotic der- 
matitis. Aust. J. Exp. Biol. Med. Sci. 39:463-476.

20. Schachman, H. K. 1957. Ultracentrifugation, diffusion, and viscometry, p. 32-103. In S. P. Colwick and N. O. Kaplan (ed.), Methods in enzymology, vol. 4. Academic Press Inc., New York.

21. Schildkraut, C. L., J. Marmur, and P. Doty. 1962.
Determination of the base composition of deoxyribonucleic acid from its buoyant density in $\mathrm{CsCl}$. J. Mol. Biol. 4:430-443.

22. Sueoka, N. 1961. Variation and heterogeneity of base composition of deoxyribonucleic acids: a compilation of old and new data. J. Mol. Biol. 3:31-40. 